\title{
Learning in the COVID-19 Era: Higher Education Students and Faculty's Experience with Emergency Distance Education
}

\author{
https://doi.org/10.3991/ijet.v16i09.20711 \\ Talal Alasmari \\ University of Jeddah, Jeddah, Saudi Arabia \\ Talasmari@uj.edu.sa
}

\begin{abstract}
The main aim of the study is to explore students and faculty's experience with emergency distance education in the higher education system at the time of COVID-19. This research has employed a quantitative approach where survey questionnaire was used as the instrument for data collection. The data was collected from teachers and students separately. The sample of teachers was 916 and the sample of students was 4623. For both the questionnaires, three point and five-point Likert scale were used to record the responses. The results of this research have indicated that emergency distance education impacted learning experience of teachers and students in Jeddah. The quantitative findings of this study have suggested that supportive and efficient infrastructure is important for the purpose of ensuring smooth learning in the COVID-19 era.
\end{abstract}

Keywords - Learning, distance learning, COVID-19 era, higher education students, faculty experience, emergency distance education

\section{Introduction}

COVID-19 despite its havocs on human existence has also proved to be an agent of change for the multifaceted fields of life. Educational institutions across the globe have been forced to modify their delivery systems to the newly emerging learning impediments posed by the pandemic. The 21 st-century educational institutions though deeply embedded in technological paraphernalia had to review and revamp their existing course delivery mechanisms, learner engagement processes, and course assessment tools, especially after lockdowns in most countries of the world led to the closure of the institutions. The idea of social distancing was extended to teaching and learning which required both the teacher and the learner to work from home.

This change from face-to-face learning to an online learning environment redefined the use of online learning tools which had hitherto been considered a part of the wider repertoire of the educational support systems [1]. The move from live teaching to what can be dubbed as Emergency Distance Education (EDE) not only tested the existing educational facilities at all levels of instruction but also challenged the 
preparedness of the institutions to effectively cope with the crisis so that the teaching and learning processes are not disrupted Mukhtar et al.[2]. The paradigm shift has, therefore, opened new domains of scholarly investigation to both evaluate the effectiveness of the new EDE delivery and assessment of the instructional material as well as provide viable action plans. One plausible model of investigation can be to collect the perceptions of the students and the teachers about their experiences with the EDE systems which could provide a reliable and valid report on the strengths and weaknesses of learning with technology from home.

Since the concept of EDE was thrust upon the institutions due to the unprecedented emergency created by the COVID-19 pandemic, very few empirical studies have been conducted to date to establish the effectiveness of working remotely which includes not only course delivery but also staff meetings and other administrative tasks related to educational management [3]. Most of the research work is done by the professionals involved in the health profession which makes it context-bound to a specific setup, and thereby the findings cannot be generalized to other fields, especially higher education [4].

The higher education system in Saudi Arabia with its extended base across the kingdom is no exception [5]. It was, therefore, strongly felt that a study focusing on the higher education institutions be conducted to gauge the perceptions of the teachers and the students about their experiences with EDE [6]. It was anticipated that this study would not only provide an empirical insight into the strengths and weaknesses of EDE but also provide a data-driven future course of action for all the stakeholders involved in higher education in Saudi Arabia in particular and other contexts in general.

COVID-19 is a recent situation, therefore, there are not many studies wherein higher education students and faculty's experience with emergency distance education has been focused on. Besides, when it comes to the studies in the context of Saudi Arabia, there is a great scarcity in studies, and there is a need to conduct more studies context. Therefore, the main aim of the study is to explore student and faculty's experience with emergency distance education in the higher education system at the time of COVID-19. To attain the aim of the study, we looked:

- To assess the significance of EDE for continuity of teaching and learning during the pandemic

- To study the advantages and disadvantages of EDE in the higher education system in Saudi Arabia.

- To analyze the importance of infrastructure and support efficiency during the delivery of EDE in higher education in Saudi Arabia.

- To study the factors that affect EDE in higher education.

- To provide recommendations to higher education institutes in Saudi Arabia for improving EDE.

Based on the research objectives, the research question of the study is designed as:

What is student and faculty's experience with emergency distance education in the higher education system at the time of COVID-19? 


\section{$2 \quad$ Literature Review}

Resorting to remote or online education during natural calamities or other disruptions is not a new phenomenon. But these events have been restricted to the regional level, quite unlike the COVID-19 which overwhelmed the entire world. Research studies have also reported the changes in the delivery of educational systems during these upheavals in different times and different parts of the world. For example, following the aftermath of Hurricane Katrina, especially designed courses were offered by more than a hundred schools in the region. Lorenzo as cited in Johnson et al.[7] mentions that the teachers reported strong emotional support and empathy as a result of the virtual interaction among the students. Similarly, the development of online teacher communities during the New Zealand earthquakes has been reported to create enhanced professional practices among the teachers Tull et al. as cited in Johnson et al. [7].

This chapter is divided into various sections. At the outset, the concept of emergency distance learning is explained. The significance of EDE for continuity of teaching and learning during pandemic is analysed. The challenges of integrating EDE in higher education will be analysed. A conceptual framework is presented based on key factors that affect the EDE. The main findings of this chapter are encapsulated at the end.

\subsection{Emergency Distance Learning (EDE)}

An alternative and unplanned method for delivering instructions from a distance when physically located in a classroom with students are not possible referring to "emergency distance or remote learning" [8]. The current outbreak of COVID-19 has greatly spurred educators to deliver instructions from a distance. The place of online learning may be taken by emergency distance learning and similar components share by it as online learning share [9]. However, because of its design, EDE is different from online learning. It has been indicated that there is a likelihood that EDE will experience remarkable growth and popularity because of the transformation of faceto-face course to online delivery [10].

\subsection{Pros and cons of EDE in the higher education system}

It has been analysed that EDE helps to ensure remote learning, which is manageable. With the help of EDE, continuous faculty development can be ensured in the time of pandemic [3]. This kind of learning is manageable for students and teachers and teaching materials could conveniently be accessed by them. Furthermore, in the administrative tasks, such as marking attendance and recording of lectures, it also provided great convenience. A study conducted by Tokuç and Varol [11] revealed that both teachers and students have an opinion that student-centeredness during this lockdown situation has been encouraged by the online learning modalities. 
The quality of self-directed learning is greatly encouraged by it and they learned asynchronously at any time in a day.

In addition to the above advantages, it has been inferred by Setiawan [12] that EDE provides a safer and more accessible environment. In this kind of environment, students can continue their process of learning without having the risk of getting affected by the virus. Besides, Ahn [4] opines that EDE can improve the academic achievements of students if the students properly adopted it. Data can easily be shared and lectures can be recorded by students [13]. In addition to this, EDE can help students communicate with professors via the chat window. This helps to ensure realtime communication and improve expression.

In the existing literature, shortcomings of remote learning have also been welldocumented. It has been assessed that 'network instability' is one of the most frequent complaints about EDE. Concerning this [14] opines that Instability in the network during the process of distance learning can result in a waste of time. Unilateral interaction is also found as a problem [4], [12]. In this regard, It has been observed that in EDE there is a lack of direct interaction.

For students who have their hearts set on the traditional college experience, online learning loses appeal for them. Hilburg et al. [13] infer that students can have a feeling of isolation in the absence of on-campus interactions with educators. In a study put forward by [14] demonstrated social isolation as the main reason that spurs students to withdraw from their studies. which leaves online learning has stigma around it. [15]. Additionally, in some studies, it has been pointed out that EDE can be difficult to coordinate for the students prone to procrastination. The majority of online learning is dependent on a student's ability to complete self-directed work.

\subsection{Challenges of integrating EDE in the higher education system in response to COVID-19 pandemic}

The emergency created by the COVID-19 has brought human life and technology closer than ever before but with the strongly felt need of shift and adaptation to the use of information technology (IT) in every sphere of human activity [16]. For educational institutions, the new scenario means a change in focus on a curriculum that is already well integrated with technology. For others, it requires both cultural and technological adaptations. [17].

In 2020, the United Nations Educational, Scientific and Cultural Organization (UNESCO) has estimated that COVID-19 affected 1,186,127,211 learners worldwide which approximately makes $67.7 \%$ of the overall registered students in 144 countries [18]. The World Bank Report in 2020 outlines the prompt transformation to education technology and distance education modalities in different countries. Countries such as China, Finland, Bulgaria, and Saudi Arabia had implemented e-learning environments.[19].

Because of the emerging situation, there has been confusion in understanding the notion and application of online learning. Hodges et al. as cited in Johnson, Veletsianos, and Seaman [7] come up with a more plausible definition of the term than its generic concept and which suits the contemporary use: "a temporary shift of 
instructional delivery to an alternate delivery model due to crisis circumstances [which] involves the use of fully remote teaching solutions for instruction or education that would otherwise be delivered face-to-face or as blended or hybrid courses and that will return to that format once the crisis or emergency has abated".

Following Goh and J. Sandars [17] that e-learning systems can, therefore, involve the use of IT and can be either synchronous or asynchronous or both. Synchronous course delivery refers to the direct interactions between the moderator and the students. Asynchronous learning involves more learner autonomy since the course material is made available to the students via other media. [20].

There have been various challenges to staff, administrators, and students brought by the unprecedented situation in the wake of COVID-19. [21] that for the education system even in the best of circumstances, transitioning to online learning at scale is a formidable task. The study further reveals that there are profound equity concerns raised by moving to online learning. Furthermore, Huang et al. [22] demonstrated that The advantage of online learning is most likely to be taken by highly motivated learners, especially those with previous experience in online learning.

In addition to the above challenges of integrating EDE in the higher education system in response to the COVID-19 pandemic, the World Bank has also highlighted several challenges [23]. In providing users and teachers with a way to ensure that to broader educational objectives within an education system, the learning opportunities provided correspond, organising digital educational content to align with existing curricula can be critical [24]. Furthermore, it has also been analysed that there is the critical importance of making content available on a wide variety of devices. Online needs of staff teaching should also be supported, which is also challenging sometimes.

\subsection{Significance of EDE for continuity of teaching and learning during pandemic}

The growing importance of emergency distance learning has been welldocumented in various studies. It has been analysed that effective use of instructional material with visual, auditory, audio-visual and multimedia content is considered distance education [25]. There have been profound efforts made in studies to discuss the role of distance education in providing an accessible learning environment for all levels of formal education. Bennardo et al. [26] opine that there can be a much better quality of education provided in on-campus courses by distance education. Moreover, Barnes [3] infers that to address pedagogical challenges faced in onsite courses; distance learning can be used with a multitude of strategies and tools.

The recent outbreak of COVID-19 has greatly accentuated the importance of distance learning. Due to the serious outbreak, the major population of the world is in quarantine. [27]. This has made institutions from offline mode to emergency distance learning. EDE methods and processes can be very effective in this situation of crisis. Chang and Yano [19] stated that EDE is student-centred and a great deal of flexibility in terms of time and location can be offered by it [10]. A study conducted by Chen, Kaczmarek, and Ohyama [28] reveals that based on the needs of learners, the methods of e-learning can enable instructors to customize processes and procedures. Moreover, 
a collaborative and interactive learning environment can be created it where immediate feedback can be given by students and queries can be asked quickly and learning can be improved.

The education industry has greatly been pushed online in Saudi Arabia by the coronavirus disease. And it has been stated by the Saudi Minister of Education Hamad Al-Sheikh that because of COVID-19, blended education has become a new norm. [29].

\subsection{Factors affecting EDE in higher education}

In previous studies, there have been various factors identified that can affect emergency distance learning. Therefore, in this section, key factors are identified and critically discussed and analysed. These factors are:

Quality of infrastructure and support efficiency: Three types of supports are well-documented in previous studies for the effectiveness and efficiency of EDE. These types include academic, administrative, and technical. Concerning academic support, it has been inferred by Domenici [21] that substantial engagement of instructors and their feedback is base of academic support. Aky1ld1z [6] opines that Administrative services about functioning within the institution as a student are dealt with by administrative support. And it has been demonstrated that content delivery is imperative to support the technical side of the learning, for instance, Toquero [30] pointed out that issues will come up eventually even in a perfect setup. Therefore, there is always a need for technical support. As all the three types of supports are imperative, Barnes [3] suggested that with the evaluation of the courses, all these support activities ought to be regularly evaluated.

It has been observed that there is a need for institutions to provide adequate training and support for the instructors. Domenici [21] indicated that disappointment can be caused by the lack of proper knowledge of tools and the principles of course design. Some studies have emancipated that a singular vision for distance learning ought to be developed. [31]. Moreover, disparate systems across the board ought to be avoided by institutions as long as they are specialised requirements through which the change of the learning tools is justified.

When it comes to infrastructure support, the quality of IT infrastructure is crucial to play in the effective delivery of emergency distance learning. The inclusion of IT in education can also be employed to manage educational affairs during this emergency [32]. Keis et al.[33] refer to the flexibility of online learning over face-to-face learning which is more time and resource-intensive. Delen and Liew [34] argue that the use of IT in education is likely to help students identify implementing ways to promote selfdirected learning which is predominantly personal, behavioral, and environmental.

However, the use of IT in education is not without its limitations. Wicaksono and Rachmadyanti [35] opine that teaching through technology can adversely impede the quality of teaching through technology. The interaction between the moderator, the student, and the instructional material can be disrupted. [36]. In a study conducted by Mukhtar et al.[2], both the faculty members and students viewed inefficiency to teach 
psychomotor skills, resource intensiveness, and mismanaged decorum during sessions as limitations of online learning.

The researchers also discovered that though good for theoretical instruction, online teaching tools proved ineffective for practical and clinical work. Fauzi and Khusuma's [37] research revealed that the teachers despite their familiarity with the context of online learning could not effectively cope with the instructional material. The transition from face-to-face learning to EDE during emergencies needs a strong realization and understanding.

Instructor characteristics: In the effectiveness of EDE, there is a central role played by an instructor. Chang and Yano [26] remarked that the effects on learning cannot be just determined by the technology, but the implementation of the technology by the instructor is pivotal [28]. There are three important characteristics of instructors that have profoundly been stressed by researchers. It has been insinuated by Prokopenko \& Berezhna [15] that students often feel isolated without classroom interaction in a distributed learning environment.

It has been analysed that with distance learning, there is a popular misconception associated. The misconception is that there is no need for an instructor in distance learning. However, this assumption has been denied by Tzivinikou ,Charitaki and Kagkara [9] while studying the impact of interactivity on learning. It has been reflected that the test performance of a student is improved, and the overall positive impression is created by increase student involvement. Chang and Yano [26] inferred that teachers' roles should not be confined to overseeing the progress of students. Students should be interacted with.

Consistent with the above information, Lee [38] opined in his study that in EDE, there are frequently technical problems faced by students. An interactive teaching style ought to be practiced by the instructor. Adnan and Anwar [5] remarked that an instructor with design capabilities is essential for an online course. Online course development is labour-intensive.

Student characteristics: There are varieties of student characteristics identified in the literature that affect the effectiveness of EDE. Such variables are maintained by Lee [38] that personality, having a computer at home, and prior experience. It has been assessed that towards computers, the variables may produce gender differences. Aky1ldz [6] found in his survey that in the usage of computers at school, males generally dominate. There is another important gender-related variable found in the study of Domenici [21], which is computer experience. In addition to this, there are some other important demographic characteristics found in the study that affect the effectiveness of EDE. The characteristics include the level of education, income, age, and employment.

There might also the role played by the program in which the students are enrolled. The computer experience has interacted. It has also been suggested by Dhawan [27] that in an online competitive environment, the brightest and most motivated students may prefer to learn online. 


\section{Theoretical Framework}

There are several models used to focus on the pedagogical aspects of online and distance education. This study has utilized the online collaborative learning theory (OCL) [39]. Linda Harasim described the OCL as a new theory of learning. It aims to forge informal, formal, and non-formal education for the knowledge age. [40]. OLC derives from social constructivism. Since to solve problems through discourses and where the role of the facilitator is played by teachers as well as the member of the learning community, students are encouraged to work collaboratively.

By focusing on this theory, the delivery of distance education learning can be enhanced for students in the current situation of the pandemic. Moreover, this theory can also assist instructors as well and enable them to focus on knowledge building and use of the internet to provide a learning environment to students that will increase collaboration and reshape education for the knowledge age.

\section{$4 \quad$ Material and Methods}

\subsection{Research design}

In the present study, I decided to employ a quantitative research design, which means that only quantitative aspects are focused on by the researcher in the present study. Various reasons have propelled the researcher to use a quantitative research design in the study. The most important reason that has propelled the researcher to use this research design is that this research design has enabled the researcher to reach higher sample size [41], [42]. Therefore, by employing this research design, the researcher has reach larger number of students and instructors in higher education institutes of Saudi Arabia. This has enabled the researcher to obtain profound data [43].

Another reason that has spurred to use this design is to collect information quickly. Furthermore, this research relied on a quantitative research design because it also enables the researcher to eliminate biasness from the study [44]. The reason is that there is randomized sampling design used in this approach to collect information through which biasness from the study can be excluded.

\subsection{Data collection and study setting}

The primary data are collected from first-hand sources, such as interviews, surveys, observation, and focus group discussion, whereas the secondary sources are already available sources, such as books, journals, articles, newspapers, and other important sources [45]. In the present study, the researcher has collected data from the primary sources. To collect primary data, the researcher has used questionnaire survey.

When it comes to collecting data from the survey, we dispersed questionnaires amongst the instructors and student of EDE in higher education institutes of Saudi Arabia. The questionnaires are distributed among them by using the electronic 
platform "Qualtrics". The researcher has used two questionnaires to collected data. One questionnaire is dispersed among instructors of EDE, while the second is distributed among students of EDE. When it comes to the questionnaire for instructors, the researcher has used a three-point Likert-type scale (from $1=$ agree to $3=$ disagree). The questionnaire is divided into two sections. In the first section, there are questions related to the demography of the participants, while the second section is based on the questions about the advantages and disadvantages of switching to distance education. There are 4 question in demographic section, while in the second section of known as survey question contains 33 questions (14 questions related to advantages, 11 questions related to disadvantages and 8 questions are related to infrastructure and support). Therefore, in total, there are 38 questions in instructor's questionnaire. As far as second questionnaire is concerned that is dispersed among students, the researcher has used a five-point Likert-type scale (from $0=$ strongly agree to $4=$ strongly disagree) in it. There is only one section in the questionnaire wherein 25 questions are included eliciting information about student's experience of EDE.

\subsection{Sampling methods and techniques}

The sample size taken in the present study is 5539, out of which 4623 are students from higher educational institutes of Saudi Arabia, while 916 are instructors of EDE from higher education institutes of Saudi Arabia. To collect the samples, the researcher has employed the method of non-probability convenience sampling by focusing on the technique of purposive sampling [46]. A large number of a heterogeneous group of students pursuing higher education are approached by the researcher. All are sent an email wherein they have explained the objectives of the study after seeking their willingness to participate in focus group discussion. Moreover, among groups, to ensure adequate diversity of opinions, by using a maximum of variation of the sampling technique, a student in the first year through the final year (attending courses online), studying at Saudi Arabia, are recruited.

We also contacted the class leaders of the first-year class through the final-year class. The reason to contact class leaders is that they have direct contact with their classmates and instructors. In addition to this, they play the role of the connector; therefore, with the help of them, the researcher can reach other students. As far as collecting data from instructors of EDE, the researcher has visited various higher educational institutes of Saudi Arabia and several meetings with the distance learning instructors have been planned to comprehend the actual picture of the problem and getting their prior consent if they are willing to participant in the survey.

The reason to use purposive sampling by the researcher is that this researcher to save his time and money while accumulating the data. The reason is that this technique of sampling is very flexible [47]. There is an adaptive process offered by it, which provides great assistance in changing circumstances. Moreover, another important reason to use this sampling technique is that this technique enables the researcher to attain the maximum level of variations in the purposive sample. The reason is that individuals can be selected by him from a wide range of cases that are 
relevant to the issue being studied [48]. This can be done by him by taking a heterogeneous approach to this research option.

In addition to this, another imperative reason that has spurred the researcher to use the technique is that there is a very low margin of error in the information collected in purposive sampling. Given that when with a random survey, a population is approached by the researcher, there can be a significant margin of error on their conclusion. However, through purposive sampling, this margin of error can astronomically be reduced because the information he has collected comes straight from the source. There are identifiable characteristics possessed by each individual that place them into the same demographic [49]. Lastly, as per Ames, Glenton and Lewin [47], with the help of this technique, the result can be produced that are available in real-time. The reason is that the data are collected by the researcher from a specific population sample, thereby in real-time situations, the acquired information is useful.

\subsection{Data analysis}

We used frequency analysis and correlation analysis. The reason to use frequency analysis is that each of the responses obtained from the respondents through the questionnaire can be analysed by it. Besides, correlation analysis has enabled the researcher to analyse the association between independent variables and the dependent variable of the study [50]. In addition to these tests, the researcher has also conduct reliability testing to assess the reliability of the selected instrument, such as the questionnaire [51]. All the tests to analyse quantitative data are conducted through statistical software, known as SPSS.

\section{$5 \quad$ Analysis and Discussion}

\subsection{Quantitative analysis}

Reliability testing: For the purpose of assessing the consistency of the scales that were used in this research, Cronbach's Alpha for each variable has been computed. The following table indicate the results of reliability testing for the variables included in the research model:

Table 1. Reliability Testing

\begin{tabular}{|l|c|c|}
\hline \multicolumn{1}{|c|}{ Variable } & Cronbach's Alpha & No of Cases \\
\hline Infrastructure and Support Efficiency & 0.793 & 8 \\
\hline Advantages of Switching to Distance Learning & 0.896 & 14 \\
\hline Disadvantages of Switching to Distance Learning & 0.831 & 11 \\
\hline
\end{tabular}

For the purpose considering that the scale of variables are consistent and will yield similar results in different settings as well, the value of Cronbach's alpha should be greater than 0.70. As shown in the above table, the value of Cronbach alpha for each 
variables is greater than the benchmark of 0.70 thus signifying the reliability of the scale used by the researcher.

Frequency analysis: The questionnaire was constituted around three dimensions: advantages of EDE, disadvantages of EDE, and infrastructure and support efficiency. The next sections depict the frequency analysis for each dimension.

First dimension: Advantages of EDE" According to Table 2, The first question that the students were asked was related to their satisfaction with the quality of the video. In this regard, 31 percent of the students agreed while 29.2 percent of the students strongly agreed. On the other hand, 15.6 percent of the students remained undecided while 14.5 percent of them disagreed. Lastly, 9.6 percent of the students strongly disagreed to the statement.

The fourth question asked to the respondents was that they find the set-up of the virtual classroom encouraging. In response, 26.9 percent students strongly agreed while 21.4 percent of them agreed. On the other hand, 19.5 percent remained undecided and 17 percent students strongly disagreed to the statement. Lastly, 15.3 percent of them disagreed to the statement.

In response to the question that psychological distance affects my learning positively, 21.3 percent of the students strongly disagreed while 20.3 percent of them strongly agreed. However, 22.1 percent of them remained undecided and 19.6 percent disagreed. Lastly, 16.6 percent of the students agreed to the statement.

In response to the question that physical distance affects my learning positively, 21.3 percent of the respondents strongly agreed to the statement while 16.8 percent of them agreed. In addition to this, 21.1 percent of the students remained undecided and 19.5 percent of the students disagreed. However, 21.2 percent of the students strongly agreed to the question.

In response to the statement that I am satisfied with the leaning units, 30.1 percent of the respondents strongly agreed while 23.7 percent of them agreed to the statement. On the other hand, 18.2 percent of the students remained undecided and 13.4 percent of them disagreed to the statement. Lastly, 14.6 percent of them strongly disagreed to the statement.

Table 2. Frequencies Table for Items of Adnvantages of EDE

\begin{tabular}{|l|l|c|c|}
\hline \multicolumn{2}{|c|}{ Statement } & Frequency & Percent \\
\hline \multirow{4}{*}{$\begin{array}{l}\text { I am satisfied with the quality of the video } \\
\text { (1) }\end{array}$} & Strongly Disagree & 442 & $9.6 \%$ \\
\cline { 2 - 4 } & Disagree & 671 & $14.5 \%$ \\
\cline { 2 - 4 } & Undecided & 719 & $15.6 \%$ \\
\cline { 2 - 4 } & Agree & 1440 & $31.1 \%$ \\
\cline { 2 - 4 } & Strongly Agree & 1351 & $29.2 \%$ \\
\hline & Total & 4623 & $100.0 \%$ \\
\hline \multirow{4}{*}{$\begin{array}{l}\text { I find the set-up of the virtual classroom } \\
\text { encouraging (4) }\end{array}$} & Strongly Disagree & 784 & $17.0 \%$ \\
\cline { 2 - 4 } & Disagree & 707 & $15.3 \%$ \\
\cline { 2 - 4 } & Undecided & 900 & $19.5 \%$ \\
\cline { 2 - 4 } & Agree & 990 & $21.4 \%$ \\
\cline { 2 - 4 } & Strongly Agree & 4242 & $26.9 \%$ \\
\cline { 2 - 4 } & Total & 4623 & $100.0 \%$ \\
\hline
\end{tabular}


Paper-Learning in the COVID-19 Era: Higher Education Students and Faculty's Experience with...

\begin{tabular}{|c|c|c|c|}
\hline \multirow{6}{*}{$\begin{array}{l}\text { Psychological distance affects my learning } \\
\text { positively (5) }\end{array}$} & Strongly Disagree & 986 & $21.3 \%$ \\
\hline & Disagree & 905 & $19.6 \%$ \\
\hline & Undecided & 1023 & $22.1 \%$ \\
\hline & Agree & 769 & $16.6 \%$ \\
\hline & \begin{tabular}{|l} 
Strongly Agree \\
\end{tabular} & 940 & $20.3 \%$ \\
\hline & Total & 4623 & $100.0 \%$ \\
\hline \multirow{6}{*}{$\begin{array}{l}\text { Physical distance affects my learning } \\
\text { positively (6) }\end{array}$} & Strongly Disagree & 979 & $21.2 \%$ \\
\hline & \begin{tabular}{|l|} 
Disagree \\
\end{tabular} & 903 & $19.5 \%$ \\
\hline & Undecided & 977 & $21.1 \%$ \\
\hline & Agree & 778 & $16.8 \%$ \\
\hline & \begin{tabular}{|l|} 
Strongly Agree \\
\end{tabular} & 986 & $21.3 \%$ \\
\hline & Total & 4623 & $100.0 \%$ \\
\hline \multirow{6}{*}{ I am satisfied with the learning units (11) } & Strongly Disagree & 675 & $14.6 \%$ \\
\hline & Disagree & 621 & $13.4 \%$ \\
\hline & Undecided & 841 & $18.2 \%$ \\
\hline & Agree & 1095 & $23.7 \%$ \\
\hline & Strongly Agree & 1391 & $30.1 \%$ \\
\hline & Total & 4623 & $100.0 \%$ \\
\hline \multirow{6}{*}{$\begin{array}{l}\text { Using the online units was an effective way } \\
\text { to learn about the assigned topics. (12) }\end{array}$} & Strongly Disagree & 786 & $17.0 \%$ \\
\hline & Disagree & 760 & $16.4 \%$ \\
\hline & Undecided & 898 & $19.4 \%$ \\
\hline & Agree & 1012 & $21.9 \%$ \\
\hline & \begin{tabular}{|l|} 
Strongly Agree \\
\end{tabular} & 1167 & $25.2 \%$ \\
\hline & Total & 4623 & $100.0 \%$ \\
\hline \multirow{6}{*}{$\begin{array}{l}\text { Questions asked in the online units were } \\
\text { not too difficult (13) }\end{array}$} & Strongly Disagree & 632 & $13.7 \%$ \\
\hline & Disagree & 533 & $11.5 \%$ \\
\hline & Undecided & 671 & $14.5 \%$ \\
\hline & Agree & 1168 & $25.3 \%$ \\
\hline & Strongly Agree & 1619 & $35.0 \%$ \\
\hline & Total & 4623 & $100.0 \%$ \\
\hline \multirow{6}{*}{ I am satisfied with the learning units (25) } & Strongly Disagree & 623 & $13.5 \%$ \\
\hline & Disagree & 671 & $14.5 \%$ \\
\hline & Undecided & 882 & $19.1 \%$ \\
\hline & \begin{tabular}{|l} 
Agree \\
\end{tabular} & 938 & $20.3 \%$ \\
\hline & Strongly Agree & 1509 & $32.6 \%$ \\
\hline & Total & 4623 & $100.0 \%$ \\
\hline
\end{tabular}

In Addition, Table 2 shows that in response to the statement that using online units was an effective way to learn about the assigned topics, 25.2 percent of the students strongly agreed while 21.9 percent of them agreed to the statement. However, 19.4 percent of the students remained undecided and 16.4 percent of the students disagreed to the statement. Lastly, 17 percent of the students strongly disagreed to the response.

In response to the statement that question asked in the online units were not too difficult, 35 percent of the respondents strongly agreed to the statement while 25.3 percent of the agreed. On the other hand, 14.5 percent of the students remained undecided while 11.5 percent of the students disagreed. Moreover, 13.7 percent of the students strongly disagreed to the statement. 
In response to the statement that I am satisfied with the learning units, 32.6 percent of the students strongly agreed and 20.3 percent of them agreed. On the other hand, 19.1 percent of them undecided while 14.5 percent of them disagreed. Moreover, 13.5 percent of them strongly disagreed.

Second dimension: Disadvantages of EDE: According to data shown in Table 3, the second question asked to students was related to they feel disadvantaged due to this shift to distance learning. In response, $24.2 \%$ of them strongly agreed while 22.5 percent students agreed. On the other hand, 18.5 percent of them strongly disagreed while 19.2 percent remained undecided. Lastly, 15.7 percent of the students disagreed to the statement.

The third question inquired to the students was related to my classmates tend to disregard lectures because attendance is not taken by you professor. In response, 34.8 percent students strongly agreed while 24.9 percent of them agreed to the statement. In addition to this, 18 percent students remained undecided and 11.2 percent of them strongly disagreed. However, 10.9 percent of them disagreed to the statement.

In response to the question that technical aspect of the experience was challenging, most of the students strongly disagreed i.e. 30 percent while 28.1 percent of the students disagreed. In addition to this, 17.8 percent of the students remained undecided while 13.5 percent of them agreed. Lastly, 10 percent of the students strongly agreed.

In response to the statement that my participation in other courses impacts negatively on my ability to participate fully in this online course, 23 percent of the students strongly agreed to the statement while 27.9 percent of them agreed. On the other hand, 24.7 percent of the students remained undecided and 12.4 percent of them disagreed. Lastly, 11.9 percent of them strongly disagreed to the statement.

In response to the statement that my inability to see and talk to the instructor of this course impacts negatively on my ability to participate fully in this online course, 32 percent of the students strongly agreed while 25.8 percent of them agreed. On the other hand, 17.2 percent of the students remained undecided while 12.8 percent of them disagreed to the statement. Lastly, 12.3 percent of the students strongly disagreed to the statement.

Table 3. Frequencies Table for Items of Disadnvantages of EDE

\begin{tabular}{|l|l|c|c|}
\hline \multicolumn{2}{|c|}{ Statement } & Frequency & Percent \\
\hline \multirow{4}{*}{$\begin{array}{l}\text { I feel disadvantaged because of this shift to } \\
\text { distance learning (2) }\end{array}$} & Strongly Agree & 1120 & $24.2 \%$ \\
\cline { 2 - 4 } & Agree & 1039 & $22.5 \%$ \\
\cline { 2 - 4 } & Undecided & 886 & $19.2 \%$ \\
\cline { 2 - 4 } & Disagree & 724 & $15.7 \%$ \\
\cline { 2 - 4 } & Strongly Disagree & 854 & $18.5 \%$ \\
\cline { 2 - 4 } & Total & 4623 & $100.0 \%$ \\
\hline \multirow{4}{*}{$\begin{array}{l}\text { My classmates tend to disregard lectures } \\
\text { because attendance is not taken by your } \\
\text { professor (3) }\end{array}$} & Strongly Agree & 1611 & $34.8 \%$ \\
\cline { 2 - 4 } & Agree & 1153 & $24.9 \%$ \\
\cline { 2 - 4 } & Undecided & 833 & $18.0 \%$ \\
\cline { 2 - 4 } & Disagree & 506 & $10.9 \%$ \\
\cline { 2 - 4 } & Strongly Disagree & 520 & $11.2 \%$ \\
\cline { 2 - 4 } & Total & 4623 & $100.0 \%$ \\
\hline
\end{tabular}


Paper-Learning in the COVID-19 Era: Higher Education Students and Faculty's Experience with...

\begin{tabular}{|c|c|c|c|}
\hline \multirow{6}{*}{$\begin{array}{l}\text { The technical aspect of the experience was } \\
\text { challenging ( } 7)\end{array}$} & Strongly Agree & 464 & $10.0 \%$ \\
\hline & Agree & 625 & $13.5 \%$ \\
\hline & Undecided & 822 & $17.8 \%$ \\
\hline & Disagree & 1299 & $28.1 \%$ \\
\hline & \begin{tabular}{|l|} 
Strongly Disagree \\
\end{tabular} & 1413 & $30.6 \%$ \\
\hline & Total & 4623 & $100.0 \%$ \\
\hline \multirow{6}{*}{$\begin{array}{l}\text { My participation in other courses impacts } \\
\text { negatively on my ability to participate fully in } \\
\text { this online course (16) }\end{array}$} & Strongly Disagree & 550 & $11.9 \%$ \\
\hline & Disagree & 575 & $12.4 \%$ \\
\hline & Undecided & 1144 & $24.7 \%$ \\
\hline & Agree & 1289 & $27.9 \%$ \\
\hline & \begin{tabular}{|l} 
Strongly Agree \\
\end{tabular} & 1065 & $23.0 \%$ \\
\hline & Total & 4623 & $100.0 \%$ \\
\hline \multirow{6}{*}{$\begin{array}{l}\text { My inability to see and talk to the instructor of } \\
\text { this course impacts negatively on my ability to } \\
\text { participate fully in this online course (17) }\end{array}$} & Strongly Disagree & 568 & $12.3 \%$ \\
\hline & Disagree & 590 & $12.8 \%$ \\
\hline & Undecided & 793 & $17.2 \%$ \\
\hline & Agree & 1192 & $25.8 \%$ \\
\hline & Strongly Agree & 1480 & $32.0 \%$ \\
\hline & Total & 4623 & $100.0 \%$ \\
\hline \multirow{6}{*}{$\begin{array}{l}\text { My ability to participate in group work impacts } \\
\text { negatively on my ability to participate fully in } \\
\text { this online course (18) }\end{array}$} & Strongly Agree & 983 & $21.3 \%$ \\
\hline & Agree & 903 & $19.5 \%$ \\
\hline & Undecided & 742 & $16.1 \%$ \\
\hline & Disagree & 795 & $17.2 \%$ \\
\hline & Strongly Disagree & 1200 & $26.0 \%$ \\
\hline & Total & 4623 & $100.0 \%$ \\
\hline \multirow{6}{*}{$\begin{array}{l}\text { My other personal obligations impact negatively } \\
\text { on my ability to participate fully in this online } \\
\text { course (22) }\end{array}$} & Strongly Agree & 1550 & $33.5 \%$ \\
\hline & Agree & 1299 & $28.1 \%$ \\
\hline & Undecided & 784 & $17.0 \%$ \\
\hline & Disagree & 479 & $10.4 \%$ \\
\hline & Strongly Disagree & 511 & $11.1 \%$ \\
\hline & Total & 4623 & $100.0 \%$ \\
\hline \multirow{6}{*}{$\begin{array}{l}\text { I incur extra load by virtue of my participation } \\
\text { in this course }(23)\end{array}$} & Strongly Agree & 839 & $18.1 \%$ \\
\hline & Agree & 903 & $19.5 \%$ \\
\hline & Undecided & 1037 & $22.4 \%$ \\
\hline & \begin{tabular}{|l} 
Disagree \\
\end{tabular} & 952 & $20.6 \%$ \\
\hline & Strongly Disagree & 892 & $19.3 \%$ \\
\hline & Total & 4623 & $100.0 \%$ \\
\hline \multirow{6}{*}{$\begin{array}{l}\text { I spent more time on this course as compared to } \\
\text { each of the classroom-based courses that I have } \\
\text { participated in (24) }\end{array}$} & Strongly Agree & 979 & $21.2 \%$ \\
\hline & Agree & 862 & $18.6 \%$ \\
\hline & Undecided & 806 & $17.4 \%$ \\
\hline & \begin{tabular}{|l} 
Disagree \\
\end{tabular} & 764 & $16.5 \%$ \\
\hline & \begin{tabular}{|l|} 
Strongly Disagree \\
\end{tabular} & 1212 & $26.2 \%$ \\
\hline & Total & 4623 & $100.0 \%$ \\
\hline
\end{tabular}

Moreover, Table 3 depicts that in response to the statement that my ability to participate in group work impacts negatively on my ability to participate fully in this online course, 26 percent of the students strongly disagreed to the statement while 17.2 percent of them disagreed. On the other hand, 16.1 percent of them remained undecided while 19.5 percent of them agreed. Moreover, 21.3 percent of the students 
strongly agreed. In response to the statement that my other personal obligations impact negatively on my ability to participate fully in this online course, 11.1 percent of the students strongly disagreed while 10.4 percent of them disagreed to the statement. On the other hand, 17 percent of them remained undecided and 28.1 percent of them agreed. However, 33.5 percent of the students strongly agreed to the statement. Regarding the statement that I incur extra load by virtue of my participation in this course, 19.3 percent of the students strongly disagreed while 20.6 percent of them disagreed. On the other hand, 22.4 percent of them remained undecided and 19.5 percent of them agreed. Moreover, 18.1 percent of them stringy agreed to the statement. Lastly, in response to the statement that I spent more time on this course as compared to each of the classroom-based courses that I have participated in, 26.2 percent of the students strongly disagreed while 16.5 percent of them disagreed. On the other hand, 17.4 percent of them remained undecided and 18.6 percent of them agreed. Moreover, 21.2 percent of them strongly agreed.

\section{Third dimension: Infrastructure and Support Efficiency}

Table 4. Frequencies Table for Items of Infrastrcuture and Support Effeciency

\begin{tabular}{|c|c|c|c|}
\hline \multicolumn{2}{|l|}{ Statement } & Frequency & Percent \\
\hline \multirow{6}{*}{$\begin{array}{l}\text { Distance teaching is as good as normal } \\
\text { teaching ( } 8)\end{array}$} & Strongly Disagree & 1282 & $27.7 \%$ \\
\hline & Disagree & 828 & $17.9 \%$ \\
\hline & Undecided & 720 & $15.6 \%$ \\
\hline & Agree & 740 & $16.0 \%$ \\
\hline & Strongly Agree & 1053 & $22.8 \%$ \\
\hline & Total & 4623 & $100.0 \%$ \\
\hline \multirow{6}{*}{$\begin{array}{l}\text { I have adequate access to participate } \\
\text { effectively in online courses (9) }\end{array}$} & Strongly Disagree & 586 & $12.7 \%$ \\
\hline & Disagree & 637 & $13.8 \%$ \\
\hline & Undecided & 679 & $14.7 \%$ \\
\hline & Agree & 1137 & $24.6 \%$ \\
\hline & Strongly Agree & 1584 & $34.3 \%$ \\
\hline & Total & 4623 & $100.0 \%$ \\
\hline \multirow{6}{*}{$\begin{array}{l}\text { online courses have enhanced my ability to } \\
\text { use internet (10) }\end{array}$} & Strongly Disagree & 590 & $12.8 \%$ \\
\hline & Disagree & 578 & $12.5 \%$ \\
\hline & Undecided & 821 & $17.8 \%$ \\
\hline & Agree & 1145 & $24.8 \%$ \\
\hline & Strongly Agree & 1489 & $32.2 \%$ \\
\hline & Total & 4623 & $100.0 \%$ \\
\hline \multirow{6}{*}{$\begin{array}{l}\text { The information presented in the units was } \\
\text { clear and easy to use (14) }\end{array}$} & Strongly Disagree & 974 & $21.1 \%$ \\
\hline & Disagree & 838 & $18.1 \%$ \\
\hline & Undecided & 921 & $19.9 \%$ \\
\hline & Agree & 932 & $20.2 \%$ \\
\hline & Strongly Agree & 958 & $20.7 \%$ \\
\hline & Total & 4623 & $100.0 \%$ \\
\hline \multirow{4}{*}{$\begin{array}{l}\text { The information presented in the units was } \\
\text { interesting and useful (15) }\end{array}$} & Strongly Disagree & 643 & $13.9 \%$ \\
\hline & Disagree & 747 & $16.2 \%$ \\
\hline & Undecided & 951 & $20.6 \%$ \\
\hline & Agree & 1176 & $25.4 \%$ \\
\hline
\end{tabular}


Paper-Learning in the COVID-19 Era: Higher Education Students and Faculty's Experience with..

\begin{tabular}{|c|c|c|c|}
\hline & Strongly Agree & 1106 & $23.9 \%$ \\
\hline & Total & 4623 & $100.0 \%$ \\
\hline \multirow{6}{*}{$\begin{array}{l}\text { My level of access to computer and internet } \\
\text { connectivity impacts negatively on my } \\
\text { ability to participate fully in this online } \\
\text { course (19) }\end{array}$} & Strongly Disagree & 1308 & $28.3 \%$ \\
\hline & Disagree & 1006 & $21.8 \%$ \\
\hline & Undecided & 666 & $14.4 \%$ \\
\hline & Agree & 717 & $15.5 \%$ \\
\hline & Strongly Agree & 926 & $20.0 \%$ \\
\hline & Total & 4623 & $100.0 \%$ \\
\hline \multirow{6}{*}{$\begin{array}{l}\text { My level of access to library books and } \\
\text { other resources impacts negatively on my } \\
\text { ability to participate fully in this online } \\
\text { course (20) }\end{array}$} & Strongly Agree & 921 & $19.9 \%$ \\
\hline & Agree & 986 & $21.3 \%$ \\
\hline & Undecided & 913 & $19.7 \%$ \\
\hline & Disagree & 891 & $19.3 \%$ \\
\hline & Strongly Disagree & 912 & $19.7 \%$ \\
\hline & Total & 4623 & $100.0 \%$ \\
\hline \multirow{6}{*}{$\begin{array}{l}\text { My level of computer and internet skills } \\
\text { impacts negatively on my ability to } \\
\text { participate fully in this online course (21) }\end{array}$} & Strongly Agree & 880 & $19.0 \%$ \\
\hline & Agree & 978 & $21.2 \%$ \\
\hline & Undecided & 927 & $20.1 \%$ \\
\hline & Disagree & 881 & $19.1 \%$ \\
\hline & Strongly Disagree & 957 & $20.7 \%$ \\
\hline & Total & 4623 & $100.0 \%$ \\
\hline
\end{tabular}

According to Table 4, in response to the statement that distance teaching is as good as normal teaching, 27.7 percent of the students strongly disagreed and 17.9 percent of them disagreed to the statement. On the other hand, 15.6 percent of them remained undecided while 16 percent of them agreed. Lastly, 22.8 percent of them strongly agreed to the statement.

In response to the statement that I have adequate access to participate effectively in online course, 34.3 percent of the students strongly agreed while 24.6 percent of them agreed to the statement. However, 14.7 percent of them remained undecided while 13.8 percent of them disagreed to the statement. Lastly, 12.7 percent of them strongly disagreed to the statement.

In response to the question that online courses have enhanced my ability to use the internet, 32.2 percent of the students strongly agreed to the statement while 24.8 percent of them agreed. On the other hand, 17.8 percent of the students remained undecided and 12.5 percent of the students disagreed. Lastly, 12.8 percent of the students strongly disagreed.

In response to the statement that information presented in the units was clear and easy to use, 20.7 percent of the students strongly agreed to the statement while 20.2 percent of the students agreed. On the other hand, 19.9 percent of the students remained undecided while 18.1 percent of the students disagreed. Moreover, 21.1 percent of the students strongly disagreed to the statement.

In response to the question that information presented in the units was interesting and useful, 23.9 percent of the students strongly agreed while 25.4 percent of the students agreed. On the other hand, 20.6 percent of the students remained undecided while 16.2 percent of them disagreed. Moreover, 13.9 percent of the students strongly disagreed. 
In response to the statement that my level of access to computer and internet connectivity impacts negatively on my ability to participate fully in this online course, 20 percent of the students strongly agreed while 15.5 percent of them agreed to the statement. In addition to this, 14.4 percent of them remained undecided while 21.8 percent of them disagreed. Moreover, 28.3 percent of the students strongly disagreed.

In response to the statement that my level of access to library books and other resources impacts negatively on my ability to participate fully in this online course, 19.7 percent of the students strongly disagreed to the statement while 19.3 percent of them disagreed. In addition to this, 19.7 percent of the students remained undecided and 21.3 percent of them agreed to the statement. Moreover, 19.9 percent of the students strongly agreed to the statement.

In response to the statement that my level of computer and internet skills impacts negatively on my ability to participate fully in this online course, 20.7 percent of the students strongly disagreed while 19.1 of them disagreed to the statement. On the other hand, 20.1 percent of them remained undecided and 21.2 of them agreed to the statement. Moreover, 19 percent of them strongly agreed.

Correlation analysis: Correlation analysis has been conducted in this research in order to analyse the existence of relationship between infrastructure and support efficiency, advantages of switching to distance education and disadvantages of distance education. The following results are obtained from carrying out correlation on the dataset:

Table 5. Correlation Matrix

\begin{tabular}{|l|c|c|c|}
\hline & $\begin{array}{c}\text { Infrastructure and } \\
\text { Support Efficiency }\end{array}$ & $\begin{array}{c}\text { Advantages of Switching } \\
\text { to Distance Education }\end{array}$ & $\begin{array}{c}\text { Disadvantages of } \\
\text { Switching to Distance } \\
\text { Education }\end{array}$ \\
\hline $\begin{array}{l}\text { Infrastructure and Support } \\
\text { Efficiency }\end{array}$ & 1.000 & $.529^{* *}$ & $-.399^{* *}$ \\
\hline & & 0.000 & 0.000 \\
\hline $\begin{array}{l}\text { Advantages of Switching to } \\
\text { Distance Education }\end{array}$ & $.529 * *$ & 1.000 & $-.375^{* *}$ \\
\hline $\begin{array}{l}\text { Disadvantages of Switching } \\
\text { to Distance Education }\end{array}$ & 0.000 & & 0.000 \\
\hline & $-.399^{* *}$ & $-.375^{* *}$ & 1.000 \\
\hline
\end{tabular}

As shown in Table 5, the existence of relationship between the variables can be confirmed by examining the significance value. For rejecting the null hypothesis and stating that there is correlation between two variables, the significance value should be lower than 0.05. After rejecting the null hypothesis, the value of Pearson Correlation coefficient indicates the strength of relationship between two variables. The first independent variable of this research is advantages of switching to distance education for which the sig value is found to be 0.000 which is lower than the benchmark value hence the null hypothesis can be rejected. Consequently, the results indicated that there is a significant relationship between advantages of switching to distance education and infrastructure and support efficiency. The value of Pearson 
Correlation Coefficient for this variable is 0.529 which means that the strength of relationship is moderately high. As the sign for the correlation coefficient is positive hence there is a direct relationship between the two.

The second independent variable of this research is advantages of switching to distance education for which the sig value is found to be 0.000 which is lower than the benchmark value hence the null hypothesis can be rejected. Consequently, the results indicated that there is a significant relationship between disadvantages of switching to distance education and infrastructure and support efficiency. The value of Pearson Correlation Coefficient for this variable is -0.399 which means that the strength of relationship is moderately high. As the sign for the correlation coefficient is negative hence there is an inverse relationship between the two.

\subsection{Discussion}

Based on the above analysis, it has been determined that there is significant relationship among the Infrastructure and Support Efficiency and Advantages of Switching to Distance Education. It also aligns with the findings of Keis et al. [33] refer to the flexibility of online learning over face-to-face learning which is more time and resource-intensive. In consistent with findings in [3], [6], [21], this finding stresses the importance of institutional support to ensure the academic continuity in the time of school closure. This support must exceed the technical level of support to include pedagogical support for both teachers and students.

On the other hand, the relationship of Infrastructure and Support Efficiency was also determined to significant with the Disadvantages of Switching to Distance Education. However, this relationship was negative among the variables. It has also been argued in the study of Wicaksono and Rachmadyanti [35] that variance in the type, size, and use of media; unavailability of the IT tools with the students; and technical deficit among the teachers and students can adversely impede quality of teaching through technology. Supported by [2] and [38], this finding demonstrates how inadequate infrastructure and support reduces the effectiveness of distance education and disrupts learning, which ultimately results in less achievement of learning outcomes.

With respect to the impact, it has been determined through the analysis that there is significant effect of Advantages of switching to distance education over the infrastructure and support efficiency. The effect was determined to be positive which depicts that the Advantages of Switching to Distance Education will lead to increase in the infrastructure and support efficiency. It has also been stated in the study of Fauzi and Khusuma's [37] research revealed that the teachers despite their familiarity with the context of online learning could not effectively cope with the instructional material, planning, delivery, and assessment of online learning. Therefore, higher education institutions must also have equal investment in infrastructure and support, since both of them go hand in hand. Infrastructure on its own cannot optimize learning and teaching without proper technical and pedagogical support. 


\section{Conclusion}

The pandemic of Covid-19 has made it challenging for most of the students to deal with the emergency distance education. In this manner, this study has focused on determining the learning in the Covid-19 era with respect to higher education students and faculty's experience with the emergency distance education. The results of this research have indicated that emergency distance education impacted learning experience of teachers and students in University of Jeddah. The quantitative findings of this study have suggested that supportive and efficient infrastructure is important for the purpose of ensuring smooth learning in the COVID-19 era. Therefore, the infrastructure and support efficiency directly influence teachers and students' experiences, that require more effort from higher education institutions to invest more resources in infrastructure and support. With such an investment, students and teachers can overcome most of the reported disadvantages and challenges such as low technical skills, live interactions with teachers and peers, and heavy course load. Also, more investment in infrastructure and support will enhance all the reported advantages of emergency distance learning such as content learnability and satisfaction.

The following recommendations are provided to higher education institutes in Saudi Arabia for improving emergency distance education. First, there is a need to provide more effective infrastructure and support from the faculty. The reason is that effective emergency distance learning can only be ensured if there is proper use of IT infrastructure and devices. Therefore, it is imperative that infrastructure must be planned before online program. In this regard, the development policies can be driven by faculty and staff development systems, and policies, support from administration and technology support systems. Second, there is a need for faculty to encourage online study group. The reason is that around specific courses, these groups can help provide additional support. Besides, the students' experience of emergency distance learning can be enhanced by creating these groups, which will spur them to engage more deeply with the content of the course. Finally, there is also a need for increase social media engagement. The reason is that online students often develop feelings of isolation. Therefore, by increasing social media engagement students can be provided help to be more connected. Moreover, they can be assisted in accessing some of the same content and services available to campus students.

\section{$7 \quad$ Research Limitations and Future Direction}

Research limitations are axiomatic part of every study, and every study has to go through some limitations. Therefore, there are also some limitations associated with this study. The most important limitation of this study is that study it has only focused on the higher education institutes of Saudi Arabia, which means the findings of the study are limited to that extent. Therefore, to overcome this limitation, it can be recommended to future researchers to conduct this kind of study on other regions as well, which will help to further expand the area of this research. Furthermore, future researcher can also conduct comparative study where they can compare the findings 
of the present study based on Saudi Arabia compare with another study based on different region.

The other important limitation of this study is that the study has used quantitative research design only, which mean qualitative aspects are not considered in this study. Therefore, this can be considered as limitation of this research. In this regard, it would not be inappropriate to suggest future researchers to use qualitative research design in this study by focusing on interviews and focus group discussion. Besides, they can also use mixed research design to conduct this kind of study where they can compare both qualitative and quantitative findings with each other.

\section{$8 \quad$ References}

[1] D. Taylor, J. Grant, H. Hamdy, L. Grant, H. Marei, and M. Venkatramana, "Transformation to learning from a distance," MedEdPublish, vol. 9, Apr. 2020, https://doi.org/10.15694/mep.2020.000076.1.

[2] K. Mukhtar, K. Javed, M. Arooj, and A. Sethi, "Advantages, Limitations and Recommendations for online learning during COVID-19 pandemic era," Pakistan Journal of Medical Sciences, vol. 36, May 2020, https://doi.org/10.12669/pjms.36.covid19s4.2785.

[3] S. J. Barnes, "Information management research and practice in the post-COVID-19 world," International Journal of Information Management, vol. 55, p. 102175, Dec. 2020, https://doi.org/10.1016/j.ijinfomgt.2020.102175.

[4] S. M. Ahn, "The Influence of Academic Self-Efficacy, Critical Thinking Disposition and Problem-Solving Ability on Nursing Freshmen' College Adjustment in the Distance Education During COVID-19," Journal of Digital Convergence, vol. 18, no. 10, pp. 315323, 2020, doi: 10.14400/JDC.2020.18.10.315.

[5] M. Adnan and K. Anwar, Online Learning amid the COVID-19 Pandemic: Students' Perspectives, vol. 2, no. 1. 2020, pp. 45-51.

[6] S. T. Akyıldız, "College Students' Views on the Pandemic Distance Education: A Focus Group Discussion," International Journal of Technology in Education and Science, vol. 4, no. 4, Art. no. 4, Sep. 2020, https://doi.org/10.46328/ijtes.v4i4.150.

[7] N. Johnson, G. Veletsianos, and J. Seaman, "U.S. Faculty and Administrators' Experiences and Approaches in the Early Weeks of the COVID-19 Pandemic," Online Learning, vol. 24, Jun. 2020, https://doi.org/10.24059/olj.v24i2.2285.

[8] J. Traxler, "Distance Learning_Predictions and Possibilities," Education Sciences, vol. 8, no. 1, Art. no. 1, Mar. 2018, doi: 10.3390/educsci8010035.

[9] S. Tzivinikou, G. Charitaki, and D. Kagkara, "Distance Education Attitudes (DEAS) During Covid-19 Crisis: Factor Structure, Reliability and Construct Validity of the Brief DEA Scale in Greek-Speaking SEND Teachers," Tech Know Learn, Nov. 2020, https://doi.org/10.1007/s10758-020-09483-1.

[10] T. Ö. Karataş and H. Tuncer, "Sustaining Language Skills Development of Pre-Service EFL Teachers despite the COVID-19 Interruption: A Case of Emergency Distance Education," Sustainability, vol. 12, no. 19, Art. no. 19, Jan. 2020, https://doi.org/10.3390/su12198188.

[11] B. Tokuç, and G. Varol, "Medical Education in Turkey in Time of COVID-19," Balkan Med J, vol. 37, no. 4, https://doi.org/10.4274/balkanmedj.galenos.2020.2020.4.003. 
[12] A. R. Setiawan, "Scientific Literacy Worksheets for Distance Learning in the Topic of Coronavirus 2019 (COVID-19)." EdArXiv, Apr. 15, 2020, https://doi.org/ 10.35542/osf.io/swjmk.

[13] R. Hilburg, N. Patel, S. Ambruso, M. Biewald, and S. Farouk, "Medical Education During the COVID-19 Pandemic: Learning From A Distfrom," Advances in Chronic Kidney Disease, vol. 27, Jun. 2020, https://doi.org/10.1053/j.ackd.2020.05.017.

[14] A. A. Lapada, F. F. Miguel, D. A. R. Robledo, and Z. F. Alam, "Teachers' Covid-19 Awareness, Distance Learning Education Experiences and Perceptions towards Institutional Readiness and Challenges," International Journal of Learning, Teaching and Educational Research, vol. 19, no. 6, Art. no. 6, Jul. 2020, Accessed: Dec. 24, 2020. [Online]. Available: https://www.ijlter.org/index.php/ijlter/article/view/2231. https://doi .org/10.26803/ijlter.19.6.8

[15] S. Berezhna and I. Prokopenko, "Higher Education Institutions in Ukraine during the Coronavirus, or COVID-19, Outbreak: New Challenges vs New Opportunities," Revista Romaneasca pentru Educatie Multidimensionala, vol. 12, pp. 130-135, Jun. 2020, https://doi.org/10.18662/rrem/12.1sup2/256.

[16] M. A. Hm, “inovasi sistem pendidikan," Inspiratif Pendidikan, vol. 7, no. 2, Art. no. 2, Dec. 2018, https://doi.org/10.24252/ip.v7i2.7851.

[17] P.-S. Goh and J. Sandars, "A vision of the use of technology in medical education after the COVID-19 pandemic," MedEdPublish, vol. 9, Mar. 2020, https://doi.org/10.15694/mep. $\underline{2020.000049 .1}$

[18] UNESCO, "Education: From disruption to recovery," UNESCO, Mar. 04, 2020. https://en.unesco.org/covid19/educationresponse (accessed Dec. 25, 2020).

[19] G.-C. Chang, S. Y. | Mar 25, 2020 | Coronavirus, and Policymaking | 1, "How are countries addressing the Covid-19 challenges in education? A snapshot of policy measures," The Education and Development Forum (UKFIET), Mar. 25, 2020. https://www.ukfiet.org/2020/how-are-countries-addressing-the-covid-19-challenges-ineducation-a-snapshot-of-policy-measures/(accessed Dec. 24, 2020). https://doi.org/10.17 87/68b11faf-en

[20] R. Rasmitadila et al., "The Perceptions of Primary School Teachers of Online Learning during the COVID-19 Pandemic Period: A Case Study in Indonesia," Journal of Ethnic and Cultural Studies, vol. 7, p. 90, Jul. 2020, https://doi.org/10.29333/ejecs/388.

[21] V. Domenici, "Distance Education in Chemistry during the Epidemic Covid-19," Substantia, pp. 961-961, Jun. 2020, doi: 10.13128/Substantia-961.

[22] R. Huang, A. Tlili, T.-W. Chang, X. Zhang, F. Nascimbeni, and D. Burgos, "Disrupted classes, undisrupted learning during COVID-19 outbreak in China: application of open educational practices and resources," Smart Learning Environments, vol. 7, no. 1, p. 19, Jul. 2020, https://doi.org/10.1186/s40561-020-00125-8.

[23] P. Iyer, K. Aziz, and D. M. Ojcius, "Impact of COVID-19 on dental education in the United States," J Dent Educ, vol. 84, no. 6, pp. 718-722, Jun. 2020, https://doi.org/10.1002/jdd.12163.

[24] G. Orhan and ö. Beyhan, "teachers'perceptions and teaching experiences on distance education through synchronous video conferencing during covid-19 pandemic." Social Sciences and Education Research Review Volume 7, Issue 1, 2020.

[25] N. F. Katzman and M. P. Stanton, "The Integration of Social Emotional Learning and Cultural Education into Online Distance Learning Curricula: Now Imperative during the COVID-19 Pandemic," Creative Education, vol. 11, no. 09, Art. no. 09, Sep. 2020, https://doi.org/10.4236/ce.2020.119114. 
[26] B. F, B. C, F. L, and G. A, "COVID-19 is a challenge for dental education-A commentary.," Eur J Dent Educ, vol. 24, no. 4, pp. 822-824, Jun. 2020, doi: 10.1111/eje.12555.

[27] S. Dhawan, "Online Learning: A Panacea in the Time of COVID-19 Crisis," Journal of Educational Technology Systems, vol. 49, no. 1, pp. 5-22, Sep. 2020, https://doi.org/ $\underline{10.1177 / 0047239520934018}$

[28] E. Chen, K. Kaczmarek, and H. Ohyama, "Student perceptions of distance learning strategies during COVID-19," J Dent Educ, Aug. 2020, https://doi.org/10.1002/jdd.12339.

[29] O. C. DIAZ, "Distance learning is here to stay, Saudi education minister says," Arab News, Jeddah, Saudi Arabia, Nov. 22, 2020.

[30] C. M. Toquero, "Challenges and Opportunities for Higher Education amid the COVID-19 Pandemic: The Philippine Context," PEDAGOGICAL RES, vol. 5, no. 4, p. em0063, Apr. 2020, https://doi.org/10.29333/pr/7947.

[31] Y. Kesendere, A. Ş. Sakin, and A. K. Acar, "Educators' views on online/distance violin education at Covid-19 outbreak term," Journal for the Interdisciplinary Art and Education, vol. 1, no. 1, Art. no. 1, Jun. 2020.

[32] C. Cholik, "pemanfaatan teknologi informasi dan komunikasi untuk meningkatkan pendidikan di indonesiA | Syntax Literate; Jurnal Ilmiah Indonesia," Accessed: Dec. 24, 2020. [Online]. Available: http://www.jurnal.syntaxliterate.co.id/index.php/syntax-literate/ article/view/130. https://doi.org/10.36418/syntax-literate

[33] O. Keis, C. Grab, A. Schneider, and W. Öchsner, "Online or face-to-face instruction? A qualitative study on the electrocardiogram course at the University of Ulm to examine why students choose a particular format," BMC Med Educ, vol. 17, no. 1, p. 194, Nov. 2017, https://doi.org/10.1186/s12909-017-1053-6.

[34] E. Delen and J. Liew, "The Use of Interactive Environments to Promote Self-Regulation in Online Learning: A Literature Review," European Journal of Contemporary Education, vol. 15, pp. 24-33, Mar. 2016, https://doi.org/10.13187/ejced.2016.15.24.

[35] V. D. Wicaksono and P. Rachmadyanti, "Pembelajaran Blended Learning Melalui Google Classroom Di Sekolah Dasar," p. 9.

[36] R. M. Bernard et al., "A Meta-Analysis of Three Types of Interaction Treatments in Distance Education," Review of Educational Research, vol. 79, no. 3, pp. 1243-1289, Sep. 2009, doi: 10.3102/0034654309333844.

[37] I. Fauzi and I. H. S. Khusuma, "Teachers' Elementary School in Online Learning of COVID-19 Pandemic Conditions," Jurnal Iqra': Kajian Ilmu Pendidikan, vol. 5, no. 1, Art. no. 1, Jun. 2020, https://doi.org/10.25217/ji.v5i1.914.

[38] J. M. Lee, "An Exploratory Study on Effects of Loneliness and YouTube Addiction on College Life Adjustment in the Distance Education During COVID-19," The Journal of the Korea Contents Association, vol. 20, no. 7, pp. 342-351, 2020, doi: 10.5392/JKCA.2020.20.07.342.

[39] A. Margaliot and D. Gorev, "Once they've Experienced it, will Pre-Service Teachers be Willing to Apply Online Collaborative Learning?" Computers in the Schools, vol. 37, pp. 217-233, Oct. 2020, https://doi.org/10.1080/07380569.2020.1834821.

[40] S. Salim and S. Masitah, "Student's intention to use wikis for Online Collaborative Learning (OCL)," undefined, 2016. /paper/Student\%27s-intention-to-use-wikis-for-Online(OCL)-Salim-Masitah/fe860baaf021ed97014535781800e889287fa1c2 (accessed Dec. 24, 2020).

[41] J. Creswell, "Research Design," SAGE Publications Inc, Dec. 04, 2020. https://us.sag epub.com/en-us/nam/research-design/book255675 (accessed Dec. 24, 2020). 
[42] J. Schoonenboom and R. B. Johnson, "How to Construct a Mixed Methods Research Design," Köln Z Soziol, vol. 69, no. 2, pp. 107-131, Oct. 2017, https://doi.org/10.100 7/s11577-017-0454-1.

[43] S. F. Turner, L. B. Cardinal, and R. M. Burton, "Research Design for Mixed Methods: A Triangulation-based Framework and Roadmap," Organizational Research Methods, vol. 20, no. 2, pp. 243-267, Apr. 2017, https://doi.org/10.1177/1094428115610808.

[44] P. Leavy, "Research Design: Quantitative, Qualitative, Mixed Methods, Arts-Based, and Community-Based Participatory Research Approaches. New York, NY: The Guilford Press. ISBN 9781462514380. 300 pp. (Paperback)," Family and Consumer Sciences Research Journal, vol. 47, no. 1, pp. 101-102, 2018, doi: https://doi.org/10.1111/ fcsr.12276.

[45] D. Barrett and A. Twycross, "Data collection in qualitative research," Evid Based Nurs, vol. 21, no. 3, pp. 63-64, Jul. 2018, https://doi.org/10.1136/eb-2018-102939.

[46] I. Etikan, "Comparison of Convenience Sampling and Purposive Sampling," American Journal of Theoretical and Applied Statistics, vol. 5, p. 1, Jan. 2016, https://doi.org/ 10.11648/j.ajtas.20160501.11.

[47] H. Ames, C. Glenton, and S. Lewin, "Purposive sampling in a qualitative evidence synthesis: a worked example from a synthesis on parental perceptions of vaccination communication," BMC Medical Research Methodology, vol. 19, no. 1, p. 26, Jan. 2019, https://doi.org/10.1186/s12874-019-0665-4.

[48] S. Campbell et al., "Purposive sampling: complex or simple? Research case examples," Journal of Research in Nursing, vol. 25, no. 8, Art. no. 8, Dec. 2020, doi: $10.1177 / 1744987120927206$.

[49] I. Etikan and K. Bala, "Sampling and sampling methods, Biometrics \& Biostatistics International Journal. Volume 5, no. Issue 6, May 2017, https://doi.org/10.15406/bbij. 2017.05.00149.

[50] S. Chandra Kafle, "Correlation and Regression Analysis Using SPSS,” Dec. 2019.

[51] H. Taherdoost, "Validity and Reliability of the Research Instrument; How to Test the Validation of a Questionnaire/Survey in a Research," International Journal of Academic Research in Management, vol. 5, pp. 28-36, Jan. 2016, https://doi.org/10.2139/ssrn.32 $\underline{05040 .}$

\section{Author}

Talal Alasmari works at University of Jeddah in Saudi Arabia. Author can be reached through mail Talasmari@uj.edu.sa

Article submitted 2020-12-22. Resubmitted 2021-01-19. Final acceptance 2021-01-19. Final version published as submitted by the authors. 